Document downloaded from:

http://hdl.handle.net/10251/47167

This paper must be cited as:

España Giner, JM.; Fages, E.; Moriana Torró, R.; Boronat Vitoria, T.; Balart Gimeno, RA. (2012). Antioxidant and antibacterial effects of natural phenolic compounds on green composite materials. Polymer Composites. 33(8):1288-1294. doi:10.1002/pc.22254.

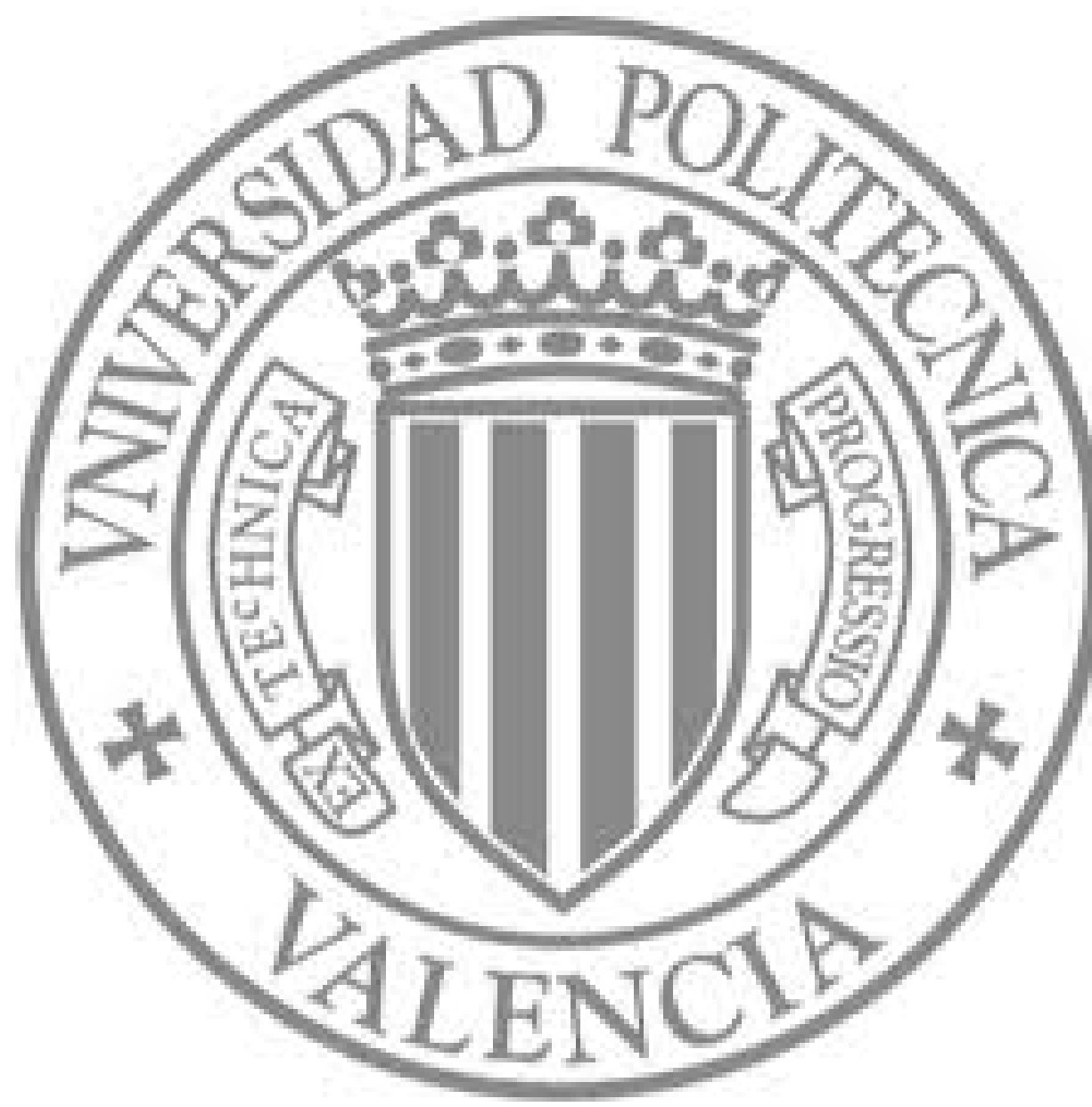

The final publication is available at

http://dx.doi.org/10.1002/pc.22254

Copyright Wiley-Blackwell 


\title{
ANTIOXIDANT AND ANTIBACTERIAL EFFECTS OF NATURAL PHENOLIC COMPOUNDS ON GREEN COMPOSITE MATERIALS.
}

\author{
J.M. España ${ }^{1}$, E. Fages ${ }^{2}$, R. Moriana ${ }^{2}$, T.Boronat ${ }^{1}$, R. Balart ${ }^{1}$. \\ ${ }^{1}$ Instituto de Tecnología de los materiales (ITM) \\ Universidad Politécnica de Valencia (campus de Alcoy) \\ Plaza Ferrandiz y Carbonell, 1, 03801 Alcoy (Alicante) Spain \\ ${ }^{2}$ Textile Research Institute (AITEX) \\ Plaza Emilio Sala,1, 03801, Alcoy (Alicante) Spain
}

\footnotetext{
${ }^{1}$ Corresponding author: J.M. España

E-mail: joesgi1@upvnet.upv.es
} 


\begin{abstract}
\end{abstract}
The aim of this study is to establish the thermal characteristics of a biocomposite (Arbofill kokos ${ }^{\circledR}$ ), stabilized with different natural phenolic additives, in order to check the antioxidant capacity of the resulting compounds on the biocomposite. The phenolic compounds used were thymol, carvacrol, $\alpha$-tocopherol and tannic acid, and the concentrations used were $0.5 \mathrm{wt} \%$ and $2 \mathrm{wt} \%$ of each compound. The results obtained were compared with the same biocomposite stabilized with an industrial antioxidant agent (octadecyl 3-(3,5-di-tert-butyl-4-hydroxyphenyl) propionate). Thermo-analytical techniques were used (DSC and TGA) to carry out the study. The antimicrobial effect of these natural phenolic compounds on the biocomposite was also studied by analyzing of the growth of bacterial colonies. The comparison between the phenolic compounds and the industrial compound showed good antioxidant action of the phenolic compounds on the base biocomposite; in all the mixtures of biocomposite and antioxidant agent the oxidation onset temperature (OOT) of the biocomposite increased. Of all the phenolic compounds studied the highest OOT was achieved with $\alpha$-tocopherol, which, compared with the temperature of the base composite, showed an increase of almost $45 \%$. 


\section{INTRODUCTION}

Biobased polymers are gaining increasing interest in the plastics industry. This is mainly due to the fact that these materials are derived from natural sources, giving them a huge advantage over petroleum-derived materials due to the ever increasing cost of petroleum. Moreover, biopolymers biodegrade very quickly and thus are more environmentally friendly as their waste material has very little impact on the environment. The use of biopolymers represents a significant reduction in the toxicity produced by traditional, petroleum-derived polymers [1].

Biopolymers represent a valid alternative to petrochemical polymers over a range of applications, including packaging and agricultural. These polymers have the advantage that they have less environmental impact, are more ecological and are available at competitive prices [2]. When these polymers are deposited in bioactive environments they degrade very quickly due to the enzyme action of the microorganisms, and the polymer breaks down into biomass, $\mathrm{CO}_{2}, \mathrm{CH}_{4}$, water and other natural substances $[2,3]$.

The development and use of biopolymers is limited due to their poor physical and chemical properties, low mechanical values and difficulties in processing $[4,5]$.

There are already a number of biopolymers that are currently being used over a range of applications. Polymers such as polylactic acid (PLA), poly- $\beta$-hydroxybutirate (PHB), poly- $\beta$-hydroxybutirate-co-valerate (PHBV), are some of the most commonly used biopolymers today. More than 140,000 tonnes of biopolymers are currently being 
produced per year world wide [2]. These materials are in constant development to improve their chemical and mechanical characteristics, with the ultimate aim of substituting the majority of petroleum-derived polymers with biopolymers.

Arbofill ${ }^{\circledR}$ is a processable thermoplastic composite. It is manufactured from modified alkali lignin obtained from pulp industry, natural additives as well as annual plant fibres like a flax or hemp and wood particles, respectively. In this study we used Arbofill kokos®. It is a biopolymer composite that contains natural fibers of coconut. Can be processed as a thermoplastic and which possesses similar properties to wood. The main components of Arbofill kokos are a lignin, cellulose, additives and coconut fiber. Products made using Arbofill show good mechanical properties in comparison with wood, have great rigidity and possess an acceptable resistance to fire without the need to incorporate flame resistant agents. There are numerous applications for this material as it is a compound that appeals to both the wood and polymer industries. The main uses for this material at present are as carcasses for electronic equipment (televisions, audio and video equipment), food industry components (containers, plates, cups, etc.), and a line of furniture is currently being designed that has the appearance of wood but which has lower production costs and produces less waste material than wood due to the degradability of coconut fiber $[6,7]$.

One of the requisites sought in this research work is resistance to oxidation of the material and one of the aims here is to check the materials resistance when used in applications where high temperatures are present. For this reason mixtures of arbofill kokos ${ }^{\circledR}$ biocomposite with natural antioxidant agents were characterized. Traditional antioxidant agents consist of synthetic compounds, mainly derived from phenol, but 
these compounds may be toxic in the case of migration of particles of the compound [ 8 , 9]. Natural antioxidants are currently being studied for use with biopolymers as they possess a similar capacity for stabilization while having a non-toxic character. Phenolic compounds such as $\alpha$-tocopherol, thymol, carvacrol, tannic acid, carnocic acid, etc. [1014], show acceptable antioxidant activity in plastics and rubbers [15], whether they are used to improve processing or melting conditions or to thermally stabilize polyolefins $[16,17]$.

Thermal degradation is responsible for a great deal of damage in many polymer materials during their processing and later use if they have to withstand high temperatures. High temperatures during processing may degrade the molecular structure of the polymer creating a more brittle material. Therefore, precise control of processing and working conditions is important to obtain a material without degradation and with good properties $[18,19]$.

In this research, we studied the efficiency of a range of phenolic compounds as antioxidant agents when used with a biocomposite. The results obtained were compared to those of the same biopolymer incorporating an industrial antioxidant (Octadecyl). In this way, it was possible to check whether the antioxidant capacity of the phenolic compounds was comparable to that of the industrial compounds. To carry out the thermal study two thermo-analytical techniques were used: DSC (both dynamic and isothermal); and TGA. Thus, we were able to also check the antibacterial action of the phenolic compounds on the biocomposites by studying the growth of bacterial colonies in samples of the biocomposite. 


\title{
EXPERIMENTAL
}

\author{
MATERIALS
}

In this study, a biocomposite, Arbofill kokos (a mixture of lignin and organic coconut fibers, distributed by Tecnaro GMBH) was used. As antioxidant agents, the compounds: thymol, supplied by Fluka analytical; carvacrol, 98\% pure, FCC, supplied by SAFC; pure tannic acid in powder form, supplied by Sigma-Aldrich; $\alpha$-tocopherol, supplied by Sigma-Aldrich; octadecyl 3-(3,5-di-tert-butyl-4-hydroxyphenyl) propionate, supplied by Sigma-Aldrich were used.

\section{Figure 1}

\section{PREPARATION OF SAMPLES}

The composite was mixed with antioxidant agents in quantities of $0.5 \mathrm{wt} \%$ and $2 \mathrm{wt} \%$, in a babyplast 6/6 injector molding machine (Cronoplast s.1., Barcelona, España) at a temperature of $180^{\circ} \mathrm{C}$. The injected material was then pelletized in a rotary grinder. For the DSC and TGA tests this pelletized material was used. For the antimicrobial analysis the material was injected into sheets of $5 \times 4.5 \times 2 \mathrm{~mm}$, in the same babyplast $6 / 6$ machine.

\section{EXPERIMENTAL TECHNIQUES}




\section{Characterization of Thermal Stability.}

\section{Differential scanning calorimetry (DSC)}

Differential scanning calorimetry (DSC) was carried out using UNE-EN ISO 11357 plastics norm "Differential scanning calorimetry (DSC)". Two DSC tests were carried out for the polymers using different thermal programs.

The first thermal program used was a dynamic program, where a sample of the composite of between 5-10mg was introduced into the DSC (METLER-TOLEDO DSC821e) apparatus, and was then subjected to the thermal program operating from 30 to $350^{\circ} \mathrm{C}$ at $5^{\circ} \mathrm{C} / \mathrm{min}$ in an air atmosphere $(250 \mathrm{~mL} / \mathrm{min})$.

The second thermal program was an isothermal program, where the sample was introduced into the DSC apparatus and the sample was taken to $200^{\circ} \mathrm{C}$ at $10^{\circ} \mathrm{C} / \mathrm{min}$ in an atmosphere of $\mathrm{N}_{2}(60 \mathrm{~mL} / \mathrm{min})$, and once this temperature was reached, it was maintained for a period of 4 hours, changing the atmosphere from $\mathrm{N}_{2}$ to air $(250 \mathrm{~mL} / \mathrm{min})$ in order to observe the oxidation time of the polymer samples.

Thermogravimetry (TGA)

TGA measurements were carried out by means of a METTLER TOLEDO TGADTA model TGA/SDTA851e/SF/1100. Samples were heated at $10^{\circ} \mathrm{C} / \mathrm{min}$, from 30 to $600^{\circ} \mathrm{C}$ in oxygen (flow rate $250 \mathrm{~mL} / \mathrm{min}$ ).

\section{Characterization of antimicrobial behavior}

Antimicrobial activity tests were conducted following the guidelines of the ATCC Test Method 100. This method allows a quantitative procedure for the evaluation 
of the antimicrobial activity of treated textile materials [20]. The selected microorganisms were Staphylococcus aureus ATCC 6538 and Escherichia coli ATCC 516. The antimicrobial activity test is based on the inoculation of the polymeric material with a suitable microorganism, so that when 20 hours of contact between the microorganism and the polymeric material have passed, the percentage reduction of the microorganism caused by the antibacterial agent will be determined [20-22]. Thus, it is possible to evaluate the antimicrobial activity with the following assessment: nonsignificant $(<0.5)$, slight $(>0.5-<1)$, significant $(\geq 1-<3)$, and strong $(\geq 3)$.

\section{RESULTS AND DISCUSSION}

\section{CHARACTERIZATION OF THERMAL STABILITY}

DSC Studies - Determination of oxidation parameters

DSC is an effective tool to check the antioxidant efficiency of the samples, measuring the maximum temperature at which the sample material degrades (oxidation onset temperature, OOT). This temperature is affected by the oxidation undergone by the polymer. The higher the OOT the greater the oxidation resistance provided by the antioxidant agent to the composite.

\section{Figure 2}


Fig. 1 shows the dynamic DSC analysis carried out between 30 and $350^{\circ} \mathrm{C}$. The different DSC curves for OOT can be seen for all the mixtures of biocomposite with the different quantities of antioxidant agents $(0.5 \mathrm{wt} \%$ and $2 \mathrm{wt} \%)$ that were evaluated in this study.

The base biocomposite (Arbofill kokos ${ }^{\circledR}$ ) shows an initial oxidation temperature of $203.9{ }^{\circ} \mathrm{C}$. As the different quantities of antioxidant $(0.5$ and $2 \%$ by weight in each compound) in the majority of cases there was a notable increase in the oxidation temperature of the biocomposite.

Looking at the phenolic compound, it was observed that for high quantities of additive $(2 \mathrm{wt} \%)$ the oxidation temperature is higher than with lower percentages $(0.5$ $\mathrm{wt} \%$ ), meaning that the antioxidant capacity of the phenolic compounds increases with the quantity that is added to the base biocomposite.

Compounds such as carvacrol and thymol are those with the lowest antioxidant capacity, increasing the OOT of the Arbofill to only 207.3 and $214.5^{\circ} \mathrm{C}$ respectively, which represents only a $10^{\circ} \mathrm{C}$ maximum increase when $2 \mathrm{wt} \%$ is added. With this same quantity, tannic acid and $\alpha$-tocopherol showed the highest antioxidant capacity with the Arbofill biocomposite, reaching OOTs of 261.7 and $279.8^{\circ} \mathrm{C}$, respectively. These phenolic compounds have such a great antioxidant capacity that they surpass the performance of the industrial antioxidant whose maximum OOT is $242.7^{\circ} \mathrm{C}$. Of the 10 samples analyzed (5 phenol compound, 2 quantities of each), the one that gave by far the highest oxidation temperature was the $\alpha$-tocopherol. The results with this compound 
are due to the effect of $\alpha$-tocopherol or vitamin E, a natural antioxidant compound [17], making tocopherol ideal as an additive in polymers.

The isothermal DSC tests were carried out at $200^{\circ} \mathrm{C}$ and this temperature was maintained for 4 hours. It was decided to carry out this test with a quantity of antioxidant of $2 \% \mathrm{wt}$ because it was with these mixtures that the higher OOTs were achieved in the previous tests. The aim with these tests was to ascertain the length of time that the biocomposite would resist before suffering oxidation.

\section{Figure 3}

Fig. 2 shows the results for oxidation induction time (OIT) at $200^{\circ} \mathrm{C}$ for the samples that contained $2 \mathrm{wt} \%$ antioxidant.

For the sample with $2 \mathrm{wt} \%$ thymol and the sample with $2 \mathrm{wt} \%$ carvacrol oxidation ocurred only a few minutes after the test temperature was reached. The sample with tannic acid showed oxidation 120 minutes after the start of the test, while the samples with $\alpha$-tocopherol and octadecyl 3-(3,5-di-tert-butyl-4-hydroxyphenyl) propionate suffered no oxidation ocurred during the 4 hours of the DSC test and the material remained stable for the entire test period.

With the results obtained in the two DSC tests, we saw that $\alpha$-tocopherol is an excellent antioxidant agent in a range of conditions and atmospheres, but acts particularly well in air atmospheres $[15,23]$. This effect can be explained by the fact that $\alpha$-tocopherol has a high density of connected structures which are very efficient at 
trapping free radical thus reducing the degradation of the biocomposite $[15,18]$. The strong activity of $\alpha$-tocopherol in limiting oxidation processes can be attributed to the structure of the original molecule and to the products of the oxidation, among which we can find dimers and trimers, as well as tocoquinones and aldehydes [16]. These products of oxidation are considered to be good antioxidants for polymers, meaning that they would help improve the antioxidant capacity of $\alpha$-tocopherol [16].

Thermogravimetric Studies

A TGA analysis of the composite samples with different compositions of phenolic compounds was carried out. A general analysis of the thermograph curves showed that the oxidation of the samples took place in two stages. The first occurred at between 200 and $250^{\circ} \mathrm{C}$, which is characteristic of the polymeric part of the biocomposite, representing around $80 \%$ of the compound, and then a second stage which occurred at between 350 and $400{ }^{\circ} \mathrm{C}$ depending on the percentage of antioxidant agent present in the compound [24].

\section{Figure 4}

\section{Figure 5}

The previous figures show the TG curves of weight loss of the thermo-oxidized samples for the different percentages of phenol compounds. In the DTG data, showed in table 1, a small peak was detected just past $400^{\circ} \mathrm{C}\left(\boldsymbol{T}_{\max 2}\right)$, corresponding to the oxidation of the coconut fiber present in the samples [25]. The value of this temperature 
indicate that the cross-linking that takes place between polymer and phenol compound greatly improves the thermal resistance of the samples, and as can be seen in table 1 , the temperature of this peak is greater for the compounds which contain $\alpha$-tocopherol and tannic acid. The first peak in the DTG data $\left(\boldsymbol{T}_{\max }\right)$ corresponds to the oxidation of the organic part of the biocomposite.

Table 1 shows the results for the temperatures obtained in the previous thermographs, as well as the quantity remaining after oxidation at high temperatures.

\section{Table 1}

In the table 1, we can observe as all temperatures are upper in the case of both amounts of $\alpha$-tocopherol and tannic acid, as we observed in the DSC tests, these compounds are the two antioxidant agents that improve very well the OOT of the biocomposite, so their temperatures are bigger than the other compounds. Also these temperatures are bigger than the petroleum-based antioxidant (octadecyl 3-(3,5-di-tert-butyl-4-hydroxyphenyl) propionate), so $\alpha$-tocopherol and tannic acid antioxidant behaviour is the best of all antioxidant compounds tested. In the column of percentage of carbon mass at $600^{\circ} \mathrm{C}$ $\left(\right.$ Char $\left._{600}\right)$, is observed that all antioxidant agents had more quantity of carbon mass than the sample of biocompsite alone, this is indicative that exists a small amount of biocomposite joined with antioxidant agent, and this amount didn't degradate in the TG tests.

\section{CHARACTERIZATION OF ANTIMICROBIAL PROPERTIES}


To determine the antimicrobial behavior shown by the phenolic compounds in the biocomposite, colonies of Staphylococcus aureus ATCC 6538 and Escherichia coli ATCC 516 bacteria were inoculated into the polymer samples with different phenol compound content. In this way, we analyzed the effect that the antimicrobial properties of the phenol compound may have on the base composite. To check this antimicrobial effect, a first count of the bacteria colony was taken at the moment of inoculation, and a second count was taken 20 hours after inoculation, to determine the growth of the colonies [20].

\section{Table 2}

Table 2 shows the values for the quantities of bacteria Staphylococcus aureus and Escherichia coli that were inoculated at the start of the antimicrobial analysis (106060 bacteria) and the bacteria found, in the recount after 20 hours of growth, in a biocomposite sample. As can be seen in the values shown in the table, the quantity of bacteria increase by up to three times the original value in the case of Staphylococcus aureus, and by up to five times in the case of Escherichia coli, after the 20 hours test time, showing that the Arbofill kokos shows no antimicrobial behavior.

\section{Table 3}

Table 3 shows the recount values for the Staphylococcus aureus and Escherichia coli bacteria after 20 hours growth for each biopolymer sample with each percentage of phenolic compounds. 
Only in the case of the bacteria Staphylococcus aureus in the compounds with $2 \mathrm{wt} \%$ of thymol and carvacrol is there a noticeable antimicrobial activity after 20 hours of culture growth time. In this case, the bacteria recounts are as follows: $<20 \mathrm{CFU} \cdot \mathrm{ml}^{-1}$ $\left[\log \left(\mathrm{CFU} \cdot \mathrm{ml}^{-1}\right) \approx 1.2\right]$ and $20 \mathrm{CFU} \cdot \mathrm{ml}^{-1}\left[\log \left(\mathrm{CFU} \cdot \mathrm{ml}^{-1}\right)=1.5\right]$ respectively, which means there is antimicrobial activity $(R)$ of 4.3 for the compound with $2 \mathrm{wt} \%$ of thymol and of 4 for the compound with $2 \mathrm{wt} \%$ of carvacrol. These values $(R)$ represent strong antibacterial activity on the bacteria Staphylococcus aureus. In the rest of the antioxidant agents the data shows that there is practically no improvement in antimicrobial activity. In most of the samples the quantity of bacteria after 20 hours growth is greater than the quantity inoculated at the start of the test, meaning that when added to the biocomposite, the phenolic compounds show no antimicrobial activity.

In the case of the bacteria Escherichia coli, none of the samples showed any signs of antimicrobial activity after 20 hours of growth. All the recounts after 20 hours showed a greater quantity of bacteria.

\section{CONCLUSIONS}

Once all the analyses to check the antioxidant capacity of the phenolic compounds added to the Arbofill biocomposite were carried out using thermo-analytical techniques, it was confirmed that the majority of the phenolic compounds improve the OOT of the composite, increasing it to a greater or lesser degree. The order of antioxidant efficiency is $\alpha$-tocopherol $>$ tannic acid $>$ thymol $>$ carvacrol. The results clearly showed that with high quantities of phenol compound (2wt\%) the antioxidant 
capacity increased. In the case of $\alpha$-tocopherol an OOT for the polymer of $269.70{ }^{\circ} \mathrm{C}$ was achieved for a quantity of $0.5 \mathrm{wt} \%$, while for a quantity of $2 \mathrm{wt} \%$ of $\alpha$-tocopherol the OOT achieved was $279.87^{\circ} \mathrm{C}$, an increase of more than $10^{\circ} \mathrm{C}$.

Of all the phenolic compounds studied, the best antioxidant performance was shown by $\alpha$-tocopherol, which gave an OOT higher than those of industrial antioxidant agents such as octadecyl 3-(3,5-di-tert-butyl-4-hydroxyphenyl) propionate. The compounds thymol and carvacrol were the only ones which gave hardly any improvement in the OOTs of the biocomposite.

Analyzing the results obtained in the antimicrobial study, of all the phenolic compounds studied the only ones which showed any antimicrobial activity against the bacteria Staphylococcus aureus were thymol and carvacrol. For quantities of compound of $2 \mathrm{wt} \%$ these showed antimicrobial activity of $(R)>3$, which means they were very efficient against these bacteria. The other compounds, in whichever of the quantities studied, showed no antimicrobial activity whatsoever given that after 20 hours the bacteria colonies increased considerably in size.

\section{ACKNOWLEDGEMENTS}

This work is part of the project IPT-310000-2010-037,"ECOTEXCOMP: Research and development of textile structures useful as reinforcement of composite materials with marked ecological character" funded by the "Ministerio de Ciencia e Innovacion", with an aid of 189540.20 euros, within the "Plan Nacional de Investigación Científica, 
Desarrollo e InnovaciónTecnológica 2008-2011” and funded by the European Union through FEDER funds, Technology Fund 2007-2013, Operational Programme on $\mathrm{R}+\mathrm{D}+\mathrm{i}$ for and on behalf of the companies." Also, Generalitat Valenciana Ref: ACOMP/2012/087 is aknowledged for financial support.

J.M. España thanks to the Polytechnic University of Valencia (UPV) their financial support through an FPI-UPV grant. 


\section{REFERENCES}

1. M.R. Nanda, M. Misra, and A.K. Mohanty, Macromolecular Materials and Engineering. 296, 8 (2011).

2. T. Mukherjee and N. Kao, Journal of Polymers and the Environment. 19, 3 (2011).

3. T. Ahmed, H. Marcal, M. Lawless, N.S. Wanandy, A. Chiu, and L.J.R. Foster, Biomacromolecules. 11, 10 (2010).

4. N. Bitinis, R. Verdejo, P. Cassagnau, and M.A. Lopez-Manchado, Materials Chemistry and Physics. 129, 3 (2011).

5. S.J. Christian and S.L. Billington, Composites Part B-Engineering. 42, 7 (2011).

6. T. Haensel, A. Comouth, N. Zydziak, E. Bosch, A. Kauffmann, J. Pfitzer, S. Krischok, J.A. Schaefer, and S.I.-U. Ahmed, Journal of Analytical and Applied Pyrolysis. 87, 1 (2010).

7. G. Scholz, J. Lohr, E. Windeisen, F. Troeger, and G. Wegener, European Journal of Wood and Wood Products. 67, 3 (2009).

8. S. Al-Malaika, C. Goodwin, S. Issenhuth, and D. Burdick, Polymer Degradation and Stability. 64, 1 (1999).

9. S. Al-Malaika and S. Issenhuth, Polymer Degradation and Stability. 65, 1 (1999).

10. P. Cerruti, M. Malinconico, J. Rychly, L. Matisova-Rychla, and C. Carfagna, Polymer Degradation and Stability. 94, 11 (2009).

11. M. De Lucia, L. Panzella, A. Pezzella, A. Napolitano, and M. d'Ischia, Tetrahedron. 62, 6 (2006).

12. A. Lopez-Rubio and J.M. Lagaron, Polymer Degradation and Stability. 95, 11 (2010). 
13. T. Ojeda, A. Freitas, K. Birck, E. Dalmolin, R. Jacques, F. Bento, and F. Camargo, Polymer Degradation and Stability. 96, 4 (2011).

14. D. Pezo, J. Salafranca, and C. Nerin, Journal of Chromatography A. 1178, 1-2 (2008).

15. M. Peltzer, R. Navarro, J. Lopez, and A. Jimenez, Polymer Degradation and Stability. 95, 9 (2010).

16. M. Peltzer, J.R. Wagner, and A. Jimenez, Journal of Thermal Analysis and Calorimetry. 87, 2 (2007).

17. R.M. Suffield, S.H. Dillman, and J.E. Haworth, Journal of Vinyl \& Additive Technology. 10, 1 (2004).

18. M. Peltzer and A. Jimenez, Journal of Thermal Analysis and Calorimetry. 96, 1 (2009).

19. M. Peltzer, J. Wagner, and A. Jimenez, Food Additives and Contaminants Part a-Chemistry Analysis Control Exposure \& Risk Assessment. 26, 6 (2009).

20. E. Fages, J. Pascual, O. Fenollar, D. Garcia-Sanoguera, and R. Balart, Polymer Engineering and Science. 51, 4 (2011).

21. S.H. Jeong, Y.H. Hwang, and S.C. Yi, Journal of Materials Science. 40, 20 (2005).

22. E.-R. Kenawy, A.E.-R.R. El-Shanshoury, N.O. Shaker, B.M. El-Sadek, A.H.B. Khattab, and B.I. Badr, Journal of Applied Polymer Science. 120, 5 (2011).

23. M. Peltzer, A. Jimenez, L. Matisova-Rychla, and J. Rychly, Journal of Applied Polymer Science. 121, 6 (2011).

24. P. Cerruti, G. Santagata, G.G. d'Ayala, V. Ambrogi, C. Carfagna, M. Malinconico, and P. Persico, Polymer Degradation and Stability. 96, 5 (2011). 


\section{Page 19 of 28}

25. J.F. Mano, D. Koniarova, and R.L. Reis, Journal of Materials Science-Materials in Medicine. 14, 2 (2003).

1

2

3

4

5

6

10

11

12

13

14

15

16

17

18

19

20

21

22

23

24

25

26

27

28

29

30

31

32

33

34

35

36

37

38

39

40

41

42

43

44

45

46

47

48

49

50

51

52

53

54

55

56

57

58

59

60 


\section{Figure captions}

Figure 1. Chemical structures of natural phenolic additives used in this study.

Figure 2. Results of the dynamic DSC analysis, carried out at $5^{\circ} \mathrm{C} / \mathrm{min}$ from 30 to $350^{\circ} \mathrm{C}$, in which the maximum OOT of each sample of the Arbofill biocomposite were obtained. (A) Biocomposite $+0.5 \mathrm{wt} \%$ antioxidant agent; (B) Biocomposite $+2 \mathrm{wt} \%$ antioxidant agent.

Figure 3. Results of the isothermal analysis, carried out at $200^{\circ} \mathrm{C}$ for a period of 4 hours, in which the oxidation induction time (OIT) of each sample of the Arbofill biocomposite with $2 \mathrm{wt} \%$ of antioxidant agent were obtained.

Figure 4. TGA curves of the different biocomposite/antioxidant agent mixtures.Original sample and samples with $0.5 \mathrm{wt} \%$ of phenolic compounds. Thermo-gravimetric analysis carried out between 30 and $600^{\circ} \mathrm{C}$, at $10^{\circ} \mathrm{C} / \mathrm{min}$ in an atmosphere of $\mathrm{O}_{2}$.

Figure 5. TGA curves of the different biocomposite/antioxidant agent mixtures. Original sample and samples with $2 \mathrm{wt} \%$ of phenolic compounds. Thermo-gravimetric analysis carried out between 30 and $600^{\circ} \mathrm{C}$, at $10^{\circ} \mathrm{C} / \mathrm{min}$ in an atmosphere of $\mathrm{O}_{2}$. 
Table 1. Temperature of the samples at $5 \%$ weight loss $\left(\mathrm{T}_{5 \%}\right)$, maximum decomposition temperatures $\left(\mathrm{T}_{\max 1}\right.$ y $\left.\mathrm{T}_{\max 2}\right)$ and percentage of carbon mass at $600^{\circ} \mathrm{C}\left(\mathrm{Char}_{600}\right)$.

\begin{tabular}{|c|c|c|c|c|}
\hline Sample & $T_{5 \%}\left({ }^{\circ} \mathrm{C}\right)$ & $T_{\max 1}\left({ }^{\circ} \mathrm{C}\right)$ & $T_{\max 2}\left({ }^{\circ} \mathrm{C}\right)$ & Char $_{600}(\%)$ \\
\hline Arbofill original & 259.3 & 346.4 & 441.3 & 1.33 \\
\hline $\begin{array}{l}\text { Arbofill }+ \\
0.5 \mathrm{wt} \% \text { thymol }\end{array}$ & 259.0 & 346.8 & 441.7 & 1.70 \\
\hline $\begin{array}{l}\text { Arbofill }+2 \mathrm{wt} \% \\
\text { thymol }\end{array}$ & 259.3 & 349.7 & 446.1 & 1.74 \\
\hline $\begin{array}{l}\text { Arbofill }+ \\
0.5 \mathrm{wt} \% \text { carvacrol }\end{array}$ & 255.1 & 346.7 & 445.5 & 1.41 \\
\hline $\begin{array}{l}\text { Arbofill }+2 \mathrm{wt} \% \\
\text { carvacrol }\end{array}$ & 265.8 & 349.9 & 447.2 & 1.50 \\
\hline $\begin{array}{l}\text { Arbofill }+ \\
0.5 \mathrm{wt} \% \text { tannic } \\
\text { acid }\end{array}$ & 266.3 & 347.2 & 443.8 & 1.62 \\
\hline $\begin{array}{l}\text { Arbofill }+2 \mathrm{wt} \% \\
\text { tannic acid }\end{array}$ & 279.9 & 352.0 & 445.3 & 1.70 \\
\hline $\begin{array}{l}\text { Arbofill }+ \\
0.5 \mathrm{wt} \% \alpha- \\
\text { tocopherol }\end{array}$ & 282.1 & 347.5 & 446.4 & 1.75 \\
\hline $\begin{array}{l}\text { Arbofill }+2 \mathrm{wt} \% \\
\alpha \text {-tocopherol }\end{array}$ & 289.9 & 355.8 & 452.4 & 1.85 \\
\hline $\begin{array}{l}\text { Arbofill }+ \\
0.5 \mathrm{wt} \% \\
\text { octadecyl }\end{array}$ & 261.5 & 348.6 & 439.2 & 1.69 \\
\hline $\begin{array}{l}\text { Arbofill }+2 \mathrm{wt} \% \\
\text { octadecyl }\end{array}$ & 266.1 & 350.9 & 441.7 & 1.78 \\
\hline
\end{tabular}


Table 2. Values for antimicrobial activity $\left[\mathrm{CFU} \cdot \mathrm{mL}^{-1}\right.$ and $\left.\log \left(\mathrm{CFU} \cdot \mathrm{mL}^{-1}\right)\right]$ of the biocomposite samples for the bacteria Staphylococcus aureus ATCC 6538 and Escherichia coli ATCC 516.

\begin{tabular}{|l|c|c|c|}
\hline Arbofill kokos & $\begin{array}{c}\text { Staphylococcus } \\
\text { aureus }\end{array}$ & Escherichia coli \\
\hline Inoculation & $\mathbf{C F U} \cdot \mathbf{m l}^{-1}$ & 106060 & 106060 \\
\hline & $\mathbf{L o g}\left(\mathbf{C F U} \cdot \mathbf{m l}^{-1}\right)$ & 5.0 & 5.0 \\
\hline Control: $t=20 h$ & $\mathbf{C F U} \cdot \mathbf{m l}^{-1}$ & 310000 & 512000 \\
\hline & $\mathbf{L o g}\left(\mathbf{C F U} \cdot \mathbf{m l}^{-1}\right)$ & 5.5 & 5.7 \\
\hline
\end{tabular}


Table 3. Values for antimicrobial activity $\left[\mathrm{CFU} \cdot \mathrm{mL}^{-1}\right.$ y $\left.\log \left(\mathrm{CFU} \cdot \mathrm{mL}^{-1}\right)\right]$ of the biocomposite samples with different quantities of antioxidant agents after 20 hours test time for the bacteria Staphylococcus aureus ATCC 6538 and Escherichia coli ATCC 516.

\begin{tabular}{|c|c|c|c|c|}
\hline & \multicolumn{2}{|c|}{ Staphylococcus aureus } & \multicolumn{2}{|c|}{ Escherichia coli } \\
\hline Sample & $\mathrm{CFU} \cdot \mathrm{ml}^{-1}$ & $\log \left(\mathrm{CFU} \cdot \mathrm{ml}^{-1}\right)$ & $\mathrm{CFU} \cdot \mathrm{ml}^{-1}$ & $\log \left(\mathrm{CFU} \cdot \mathrm{ml}^{-1}\right)$ \\
\hline $\begin{array}{l}\text { Arbofill }+ \\
0.5 \mathrm{wt} \% \text { thymol }\end{array}$ & 210200 & 5.3 & 512200 & 5.7 \\
\hline $\begin{array}{l}\text { Arbofill }+2 \mathrm{wt} \% \\
\text { thymol }\end{array}$ & $<20$ & 1.2 & 413400 & 5.6 \\
\hline $\begin{array}{l}\text { Arbofill }+ \\
0.5 \mathrm{wt} \% \text { carvacrol }\end{array}$ & 109848 & 5.0 & 740740 & 5.9 \\
\hline $\begin{array}{l}\text { Arbofill }+2 \mathrm{wt} \% \\
\text { carvacrol }\end{array}$ & 20 & 1.3 & 147727 & 5.2 \\
\hline $\begin{array}{l}\text { Arbofill + } \\
0.5 \mathrm{wt} \% \text { tannic } \\
\text { acid }\end{array}$ & 215.000 & 5.3 & 510200 & 5.7 \\
\hline $\begin{array}{l}\text { Arbofill }+2 \mathrm{wt} \% \\
\text { tannic acid }\end{array}$ & 180500 & 5.3 & 435500 & 5.6 \\
\hline $\begin{array}{l}\text { Arbofill + } \\
0.5 \mathrm{wt} \% \alpha- \\
\text { tocopherol }\end{array}$ & 275000 & 5.4 & 510200 & 5.7 \\
\hline $\begin{array}{l}\text { Arbofill }+2 \mathrm{wt} \% \\
\alpha \text {-tocopherol }\end{array}$ & 253300 & 5.4 & 438000 & 5.6 \\
\hline $\begin{array}{l}\text { Arbofill }+ \\
0.5 \mathrm{wt} \% \\
\text { octadecyl }\end{array}$ & 253000 & 5.4 & 740200 & 5.9 \\
\hline $\begin{array}{l}\text { Arbofill }+2 \mathrm{wt} \% \\
\text { octadecyl }\end{array}$ & 250000 & 5.4 & 530000 & 5.7 \\
\hline
\end{tabular}


<smiles>Cc1ccc(C(C)C)c(O)c1</smiles>

thymol

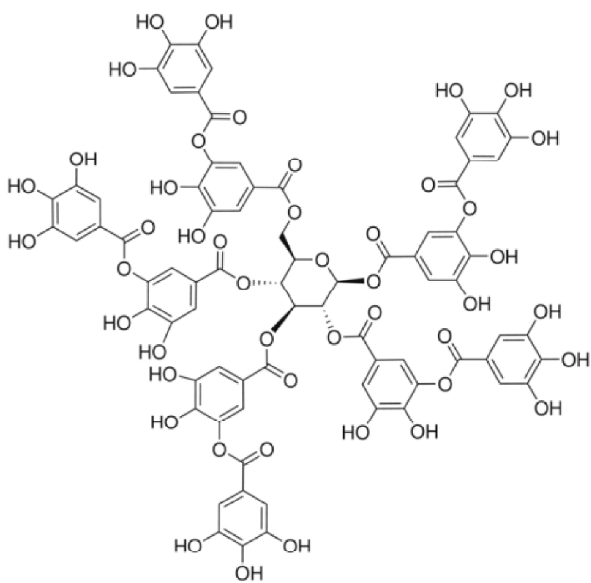

tannic acid<smiles>Cc1ccc(C(C)C)cc1O</smiles>

carvacrol

Figure 1. Chemical structures of natural phenolic additives used in this study. $309 \times 216 \mathrm{~mm}(300 \times 300$ DPI $)$ 
(A)

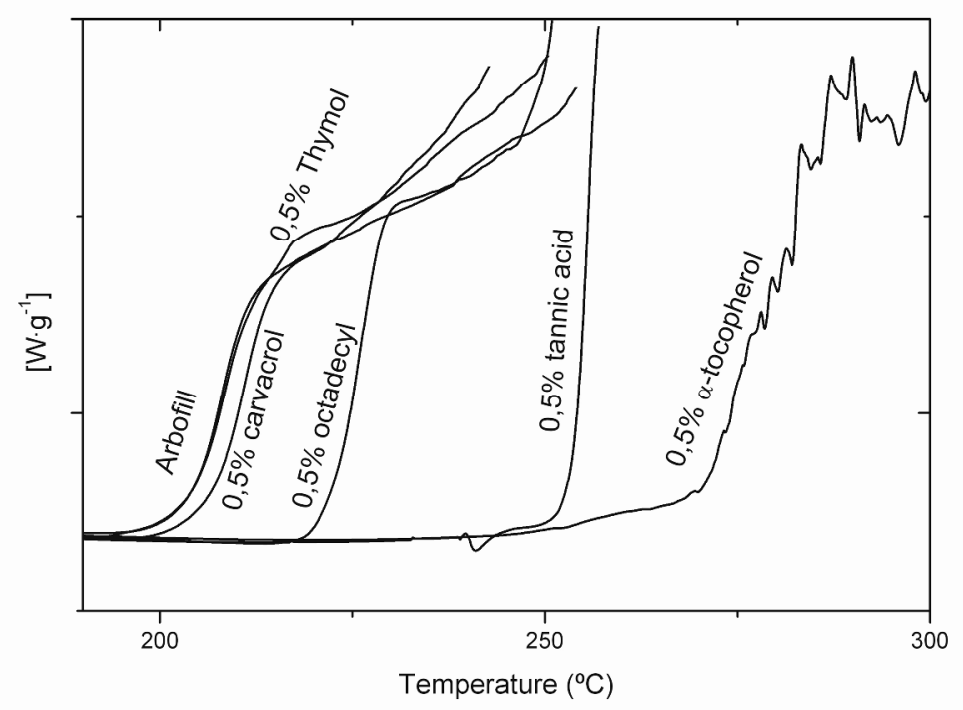

(B)

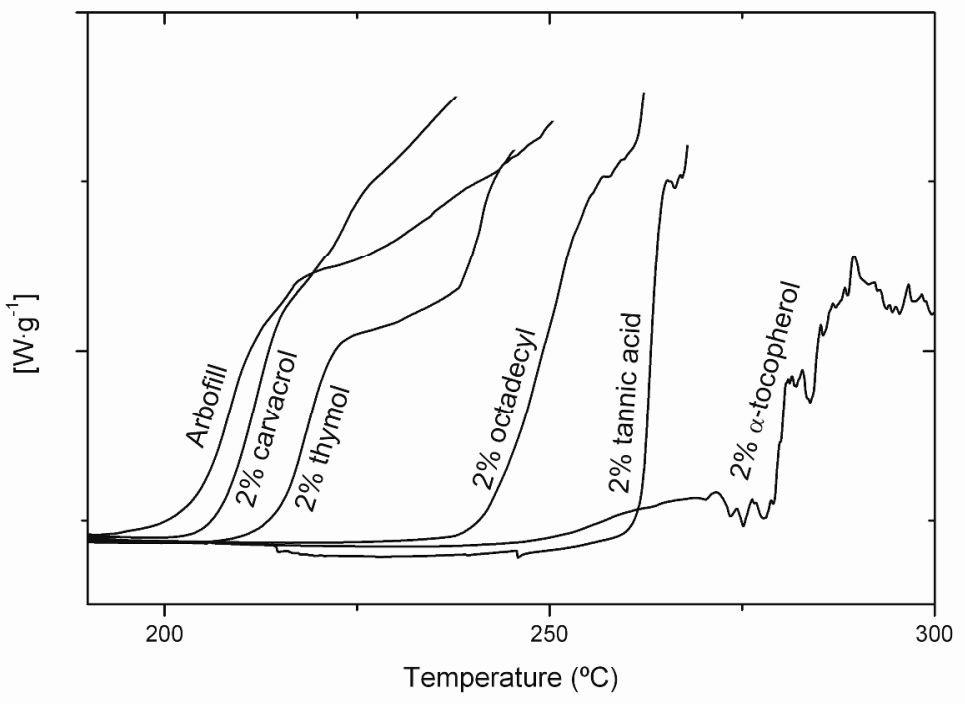

Figure 2. Results of the dynamic DSC analysis, carried out at $5{ }^{\circ} \mathrm{C} / \mathrm{min}$ from 30 to $350^{\circ} \mathrm{C}$, in which the maximum OOT of each sample of the Arbofill biocomposite were obtained. (A) Biocomposite $+0.5 w t \%$ antioxidant agent; (B) Biocomposite $+2 \mathrm{wt} \%$ antioxidant agent. $290 \times 399 \mathrm{~mm}(300 \times 300 \mathrm{DPI})$ 
Figure 3. Results of the isothermal analysis, carried out at $200^{\circ} \mathrm{C}$ for a period of 4 hours, in which the oxidation induction time (OIT) of each sample of the Arbofill biocomposite with $2 \mathrm{wt} \%$ of antioxidant agent were obtained.

$289 \times 202 \mathrm{~mm}(300 \times 300 \mathrm{DPI})$ 
Figure 4. TGA curves of the different biocomposite/antioxidant agent mixtures. Original sample and samples with $0.5 \mathrm{wt} \%$ of phenolic compounds. Thermo-gravimetric analysis carried out between 30 and $600^{\circ} \mathrm{C}$, at $10^{\circ} \mathrm{C} / \mathrm{min}$ in an atmosphere of $\mathrm{O}_{2}$. $289 \times 202 \mathrm{~mm}(300 \times 300 \mathrm{DPI})$ 
Figure 5. TGA curves of the different biocomposite/antioxidant agent mixtures. Original sample and samples with $2 \mathrm{wt} \%$ of phenolic compounds. Thermo-gravimetric analysis carried out between 30 and $600^{\circ} \mathrm{C}$, at $10^{\circ} \mathrm{C} / \mathrm{min}$ in an atmosphere of $\mathrm{O}_{2}$. $289 \times 202 \mathrm{~mm}(300 \times 300 \mathrm{DPI})$ 